\title{
Design, synthesis, and mechanism of action of 2-(3-hydroxy-5- methoxyphenyl)-6-pyrrolidinylquinolin-4-one as a potent anticancer lead
}

\author{
Yung-Yi Cheng ${ }^{\mathrm{a}}$, Chin-Yu Liu ${ }^{\mathrm{a}}$, Meng-Tung Tsai ${ }^{\mathrm{a}}$, Hui-Yi Lin ${ }^{\mathrm{a}}$, Jai-Sing Yang ${ }^{\mathrm{b}}$, Tian-Shung

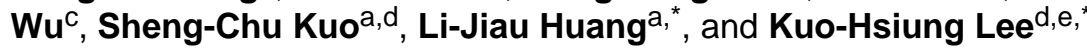 \\ aGraduate Institute of Pharmaceutical Chemistry, China Medical University, No.91 Hsueh-Shih \\ Road, Taichung, Taiwan, 40402, R.O.C. \\ bDepartment of Pharmacology, China Medical University, No.91 Hsueh-Shih Road, Taichung, \\ Taiwan, 40402, R.O.C. \\ 'Department of Chemistry, National Cheng Kung University, No. 1, Dasyue Road, Tainan, \\ Taiwan.
}

${ }^{d}$ Chinese Medicine Research and Development Center, China Medical University and Hospital, 2 Yuh-Der Road, Taichung, Taiwan, 40447, R.O.C.

eNatural Products Research Laboratories, UNC Eshelman School of Pharmacy, University of North Carolina, Chapel Hill, NC 27599, USA

\begin{abstract}
New 6- (or 6,7-) substituted 2-(hydroxyl substituted phenyl)quinolin-4-one derivatives were synthesized and screened for antiproliferative effects against cancer cell lines. Structure-activity relationship correlations were established and the most promising compound 2-(3-hydroxy-5methoxyphenyl)-6-pyrrolidin-1-ylquinolin-4-one (6h) exhibited strong inhibitory activity against various human cancer cell lines, particularly non-small cell lung cancer NCI-H522. Additional studies suggested a mechanism of action resembling that of the antimitotic drug vincristine. The presence of a C-ring $\mathrm{OH}$ group in $\mathbf{6} \mathbf{h}$ will allow this compound to be converted readily to a water soluble and physiochemically stable hydrophilic prodrug. Compound $\mathbf{6 h}$ is proposed as a new anticancer lead compound.
\end{abstract}

\section{Keywords}

2-(Hydroxyphenyl)quinolin-4-one derivatives; Antiproliferative activity; Anticancer lead development; Prodrug

In prior studies, we synthesized 2-phenylquinolin-4-one derivatives (2PQs) ${ }^{1-17}$ and identified various compounds, e.g., 2PQ-1, 2PQ-2, 2PQ-3, and 2PQ-4 (Chart1), with potent

\footnotetext{
(C) 2013 Elsevier Ltd. All rights reserved.

"Corresponding author. Tel.: +886-4-2203-0760; fax: +886-4-2203-0760; ljhuang@ mail.cmu.edu.tw. "Corresponding author. Tel.: +1-919-962-0066; fax: +1-919-966-3893; khlee@unc.edu.

Supplementary data Supplementary data associated with this article can be found in the online versions at ...

Publisher's Disclaimer: This is a PDF file of an unedited manuscript that has been accepted for publication. As a service to our customers we are providing this early version of the manuscript. The manuscript will undergo copyediting, typesetting, and review of the resulting proof before it is published in its final citable form. Please note that during the production process errors may be discovered which could affect the content, and all legal disclaimers that apply to the journal pertain.
} 
anticancer activity. ${ }^{3}$ These potential antitumor agents, however, suffer from high toxicity and poor hydrophilicity, which has limited their further development. To overcome such drawbacks of $2 \mathrm{PQs}$, we introduced a hydroxy group into the 2PQ skeleton to improve water solubility. Moreover, this type of $2 \mathrm{PQ}$ could be further converted to a water soluble prodrug. Accordingly, we synthesized a series of 2PQs with a hydroxy group on the A-ring (2PQ-5 10, Chart 2), and among them, 5-hydroxy-6-methoxy derivatives (2PQ-5, and 2PQ-6) exhibited good anticancer activity with $\mathrm{IC}_{50}$ values ranging from 0.03 to $0.11 \mu \mathrm{M}$ against HL-60, HCT116, Hep3B and NCI-H460 cell lines. ${ }^{5}$ Subsequently, 2PQ-6 was converted to a water soluble disodium monophosphate prodrug (2PQ-6P), which exhibited significant tumor growth suppression, without appreciably affecting normal biological function..$^{5}$ Based on this finding, we have now designed a new series of $2 \mathrm{PQs}$ with a hydroxy group on the C-ring (6a-k). Again, this hydroxy moiety should provide a "synthetic handle" for potential useful prodrug design. The benefits of this design are to decrease toxicity, increase hydrophility, and facilitate possible hydrophilic prodrug derivatization. This report describes the chemical synthesis, antitumor activity screening in vitro, and mechanism of action of the new series of 6- (or 6,7-) substituted 2-(hydroxyl substituted phenyl)quinolin-4-ones $(\mathbf{6 a}-\mathbf{k})$.

The synthesis of target compounds $\mathbf{6 a}-\mathbf{k}$ is illustrated in Scheme 1. As shown, variously substituted benzoic acids (1a-f) were chlorinated with thionyl chloride to afford compounds 2a-f. ${ }^{18}$ Without purification, $\mathbf{2 a - f}$ were reacted with $o$-aminoacetophenones (3a-d) ${ }^{2,3}$ to give the desired amides $(\mathbf{4 a}-\mathbf{k}),{ }^{19}$ which were then cyclized in the presence of basic dioxane solution to yield $\mathbf{5 a}-\mathbf{k} .{ }^{20}$ Catalytic hydrogenolysis of $\mathbf{5 a}-\mathbf{k}$ with palladium on active charcoal gave the final compounds, 6- (or 6,7-) substituted 2-(hydroxyphenyl)quinolin-4ones $(\mathbf{6 a}-\mathbf{k}) .{ }^{21}$ The spectroscopic data $\left({ }^{1} \mathrm{H},{ }^{13} \mathrm{C}\right.$ NMr and HR-ESIMS $)$ were consistent with the proposed structures.

The newly synthesized compounds were screened for antiproliferative activity against HL-60 leukemia, Hep3B hepatoma, NCI-H460 non-small cell lung cancer, and Detroit 551 human skin fibroblast cells. ${ }^{22,23}$ The results are given in Table 1. Among the three monohydroxy derivatives $(\mathbf{6 a}-\mathbf{c}), \mathbf{6} \mathbf{b}$ with meta-hydroxy substitution was the most potent (Table1), but showed only moderate cytotoxicity compared with 2PQ-1. Compound 6d with an additional hydroxy group at the C-ring 5-position exhibited only weak activity. Based on the structures of active compounds $\mathbf{2 P Q - 1} \sim \mathbf{4}$, we also synthesized compounds with a 3hydroxy-5-alkoxyphenyl C-ring (6e-f) and changed the A-ring substitution from 6,7methylenedioxy to 6-pyrrolidinyl $(\mathbf{6 g}-\mathbf{i}), 6$-morpholinyl $(\mathbf{6 j})$, and 6-dimethylamino $(\mathbf{6 k})$. These seven compounds (6e-k) showed the highest cytotoxicity against the HL-60 cancer cell line. With hydroxy and methoxy groups on the C-ring, the rank order of HL-60 inhibitory activity was 6-pyrrolidinyl $(\mathbf{6 h})>6$-dimethylamino $(\mathbf{6 k})>6,7$-methylenedioxy $(\mathbf{6 e})>6$-morpholinyl $(\mathbf{6 j})$. A change from $5{ }^{\prime}$-methoxy $(\mathbf{6 h})$ to $5^{\prime}$-ethoxy $(\mathbf{6 i})$ significantly increased anti-proliferative activity, but replacement with $5^{\prime}$-hydroxy $(\mathbf{6 g})$ decreased activity significantly, as also seen with $\mathbf{6 e}$ versus $\mathbf{6 d}$. While $\mathbf{6 i}$ was more potent than $\mathbf{6 h}$, unfortunately, $\mathbf{6} \mathbf{i}$ also exhibited unsatisfactory toxicity against the Detroit 551 cell line. Therefore, among compounds $\mathbf{6 a}-\mathbf{k}$, we selected $\mathbf{6 h}$ as the lead compound for further investigation, and submitted it to NCI for anticancer evaluation.

The resulting activity profile fingerprint (Table 2 and supplementary data) of $\mathbf{6} \mathbf{h}$ against the NCI-60 human cancer cell line panel indicated significant inhibitory activity against a variety of cancer cell lines. Compound $\mathbf{6} \mathbf{h}$ was particularly active against SR leukemia $\left(\log \mathrm{GI}_{50}<-8.00\right)$, MDA-MB-435 melanoma $\left(\log \mathrm{GI}_{50}<-8.00\right)$, and NCI-H522 non-small cell lung cancer $(\log \mathrm{TGI}<-8.00)$ cell lines. We also evaluated the potency of $\mathbf{6} \mathbf{h}$ in an antiproliferation assay with NCI-H522 cells. MTT assay results showed that $\mathbf{6} \mathbf{h}$ effectively inhibited proliferation of NCI-H522 cells with an IC $_{50}$ value of $42.3 \pm 1.2 \mathrm{nM}$ at $48 \mathrm{~h}-$ 
incubation. The activity profile fingerprint of $\mathbf{6} \mathbf{h}$ was further analyzed by COMPARE correlation at the $\mathrm{GI}_{50}$ level. As shown in Table 3 , the fingerprint of $\mathbf{6 h}$ correlated most closely with that of antimitotic Vinca alkaloids, such as vincristine and vinblastine. To support this supposition, we examined whether $\mathbf{6} \mathbf{h}$ has an effect on tubulin assembly. In an in vitro tubulin polymerization assay, $\mathbf{6} \mathbf{h}$ inhibited tubulin polymerization in a concentration-dependent manner, which was similar to the effects caused by vincristine and vinblastine (Figure 1A). ${ }^{24}$ Results from an in vivo tubulin assembly assay showed that $\mathbf{6 h}$ inhibited $\alpha$-tubulin and $\beta$-tubulin accumulation concentration-dependently in the cytoskeletal fraction, the same effect as vincristine and vinblastine, whereas paclitaxel caused tubulin polymerization (Figure 1B). ${ }^{25}$ Thus, the preliminary results indicated that the mechanism of action of $\mathbf{6 h}$ resembles that of vincristine and vinblastine.

In summary, 6- (or 6,7-) substituted 2-(hydroxyl substituted phenyl)quinolin-4-one derivatives were designed, synthesized, and evaluated for in vitro antitumor activity. Preliminary SAR correlations of the new analogs were established. The most promising compound $\mathbf{6 h}$ demonstrated low toxicity against a normal cell line and significant inhibition against several cancer cell lines. In addition, the results of a COMPARE analysis suggested that $\mathbf{6 h}$ might function as an antimitotic agent, such as Vinca alkaloids. Therefore, we believe that $\mathbf{6 h}$ is a promising lead compound that deserves further optimization and derivatization as a hydrophilic prodrug.

\section{Supplementary Material}

Refer to Web version on PubMed Central for supplementary material.

\section{Acknowledgments}

The investigation was supported by research grants from the National Science Council of the Republic of China awarded to S.C.K. (NSC101-2320-B-039-008). Thanks are also due to support by Grant CA177584 from the National Cancer Institute, NIH awarded to K.H.L.

\section{References and notes}

1. Kuo S-C, Lee H-Z, Juang J-P, Lin Y-T, Wu T-S, Chang J-J, Lednicer D, Paull KD, Lin CM, Hamel E, Lee K-H. J. Med. Chem. 1993; 36:1146. [PubMed: 8387598]

2. Li L, Wang H-K, Kuo S-C, Wu T-S, Lednicer D, Lin CM, Hamel E, Lee K-H. J. Med. Chem. 1994; 37:1126. [PubMed: 8164254]

3. Li L, Wang H-K, Kuo S-C, Wu T-S, Mauger A, Lin CM, Hamel E, Lee K-H. J. Med. Chem. 1994; 37:3400. [PubMed: 7932568]

4. Zhang S-X, Feng J, Kuo S-C, Brossi A, Hamel E, Tropsha A, Lee K-H. J. Med. Chem. 2000; 43:167. [PubMed: 10649972]

5. Chou L-C, Tsai M-T, Hsu M-H, Lin H-Y, Huang L-J, Kuo S-C, Wang S-H, Way T-D, Huang C-H, Qian K, Dong Y, Lee K-H. J. Med. Chem. 2010; 53:8047. [PubMed: 20973552]

6. Chen HY, Lu HF, Yang JS, Kuo SC, Lo C, Yang MD, Chiu TH, Chueh FS, Ho HC, Ko YC. Anticancer Res. 2010; 30:4187. [PubMed: 21036739]

7. Chen Y-C, Lu P-H, Pan S-L, Teng C-M, Kuo S-C, Lin T-P, Ho Y-F, Huang Y-C, Guh J-H. Biochem. Pharmaco. 2007; 74:10.

8. Wang J-P, Raung S-L, Huang L-J, Kuo S-C. Biochem. Pharmaco. 1998; 56:1505.

9. Huang L-J, Hsieh M-C, Teng C-M, Lee K-H, Kuo S-C. Bioorg. Med. Chem. 1998; 6:1657. [PubMed: 9838997]

10. Lai Y-Y, Huang L-J, Lee K-H, Xiao Z, Bastow KF, Yamori T, Kuo S-C. Bioorg. Med. Chem. 2005; 13:265. [PubMed: 15582470]

11. Xia Y, Yang Z-Y, Xia P, Bastow K. F., Tachibana, Y. Kuo S-C, Hamel E, Hackl T, Lee K-H. J. Med. Chem. 1998; 41:1155. [PubMed: 9544215] 
12. Hsu S-C, Yang J-S, Kuo C-L, Lo C, Lin J-P, Hsia T-C, Lin J-J, Lai K-C, Kuo H-M, Huang L-J, Kuo S-C, Wood WG, Chung J-G. J.Orthop. Res. 2009; 27:1637. [PubMed: 19557855]

13. Lai TY, Yang JS, Wu PP, Huang WW, Kuo SC, Ma CY, Wood WG, Chung JG. Leuk. Lymphoma. 2010; 51:2098. [PubMed: 20846096]

14. Wang SW, Pan SL, Huang YC, Guh JH, Chiang PC, Huang DY, Kuo SC, Lee KH, Teng CM. Mol. Cancer Ther. 2008; 7:350. [PubMed: 18281518]

15. Wen CC, Juang SH, Chou LC, Chung JG, Kuo SC, Yang NS. Pharm. Biol. 2012; 50:570.

16. Chang Y-H, Hsu M-H, Wang S-H, Huang L-J, Qian K, Morris-Natschke SL, Hamel E, Kuo S-C, Lee K-H. J. Med. Chem. 2009; 52:4883. [PubMed: 19719238]

17. Chou L-C, Chen C-T, Lee J-C, Huang S-M, Huang L-J, Kuo S-C, Qian K, Morris-Natschke SL, Lee K-H, Way T-D, Huang C-H, Teng C-M, Yamori T, Wu T-S, Sun C-M, Chien D-S. J. Med. Chem. 2010; 53:1616. [PubMed: 20102207]

18. Preparation of arylcarbonyl chlorides $(2 a-f)$ : Arylcarboxylic acids (1a-f) were suspended in dry THF at room temperature. Thionyl chloride and DMF were added dropwise. The reaction mixtures were stirred for $12 \mathrm{~h}$ at room temperature and then evaporated to dryness. The residues were used directly in the next step without purification.

19. Preparation of benzamides $(\mathbf{4} \boldsymbol{a}-\boldsymbol{k})$ : Into solutions of $\mathbf{1 a}-\mathbf{f}$ in dry THF were added triethylamine and $o$-aminoacetophenones $(\mathbf{3 a}-\mathbf{d}){ }^{2,3}$ The mixtures were stirred at room temperature for $12 \mathrm{~h}$ and evaporated. The residue was purified by column chromatography eluting with a mixture of $n$ hexane and EtOAc (1/1) to afford pure carboxamides $(\mathbf{4 a}-\mathbf{k})$.

20. Preparation of 2-(benzyloxy substituted phenyl)quinolin-4-ones (5a-k): A mixture of carboxamide $(\mathbf{4 a}-\mathbf{k})$ and $\mathrm{NaOH}$ was suspended in 1,4-dioxane. The reaction mixture was refluxed for $4 \mathrm{~h}$. After cooling to room temperature, the mixture was evaporated and then the residue was added to $10 \%$ $\mathrm{NH}_{4} \mathrm{Cl}$ solution. The precipitate was collected, washed with water and acetone, and then purified by silica gel column chromatography to obtain 2-(benzyloxy substituted phenyl)quinolin-4-ones $(\mathbf{5 a}-\mathbf{k})$.

21. Preparation of 2-(hydroxyl substituted phenyl)quinolin-4-ones (6a-k): A suspension of $\mathbf{5 a}-\mathbf{k}$ and palladium (10 wt $\%$ on activated carbon) in $\mathrm{MeOH}$ or $\mathrm{CH}_{2} \mathrm{Cl}_{2}$ was stirred at room temperature under hydrogen gas atmosphere for $24 \mathrm{~h}$. The precipitate was collected and dissolved in $10 \%$ $\mathrm{NaOH}$ solution and then filtered. The filtrate was acidified with dil. aq. $\mathrm{HCl}$ and the resulting precipitate was collected and washed with acetone and water to yield 2-(hydroxyl substituted phenyl)quinolin-4-ones (6a-k).

22. Cell culture: Human leukemia HL-60 and non-small-cell-lung cancer H460 cells were maintained in RPMI-1640 medium supplemented with $10 \%$ fetal bovine serum (GIBCO/BRL), penicillin (100 $\mathrm{U} / \mathrm{mL}) /$ streptomycin $(100 \mu \mathrm{g} / \mathrm{mL})(\mathrm{GIBCO} / \mathrm{BRL})$ and $1 \% \mathrm{~L}$-glutamine $(\mathrm{GIBCO} / \mathrm{BRL})$ at $37{ }^{\circ} \mathrm{C}$ in a humidified atmosphere containing $5 \% \mathrm{CO}_{2}$. Human hepatocellular carcinoma cell line Hep3B was obtained from America Type Culture Collection (Manassas, VA, USA). Hep3B cells were cultured in DMEM/F12 medium supplemented with $10 \%$ FBS and penicillin $(100 \mathrm{U} / \mathrm{mL})$ / streptomycin $(100 \mu \mathrm{g} / \mathrm{mL})$ and maintained in a humidified incubator containing $5 \% \mathrm{CO}_{2}$. Normal skin Detroit 551 cells were maintained in DMEM medium supplemented with $10 \%$ fetal bovine serum (GIBCO/BRL), penicillin $(100 \mathrm{U} / \mathrm{mL}) /$ streptomycin $(100 \mu \mathrm{g} / \mathrm{mL})(\mathrm{GIBCO} / \mathrm{BRL})$ and $1 \%$ L-glutamine (GIBCO/BRL) at $37{ }^{\circ} \mathrm{C}$ in a humidified atmosphere containing $5 \% \mathrm{CO}_{2}$. Logarithmically growing cancer cells were used for all experiments.

23. Cell viability assay: The cell viability was detected by 3(4,5-dimethythiazol-2-yl)-2,5diphenyltetrazolium bromide (MTT) assay. Cells were cultured in 96 -well plates at $37{ }^{\circ} \mathrm{C}$ and incubated with complete medium containing the vehicle (DMSO) or compounds for indicated times and concentrations. After treatment, cells were incubated with MTT solution $(1 \mathrm{mg} / \mathrm{mL}$ in $1 \mathrm{X}$ PBS) at $37^{\circ} \mathrm{C}$ for $2 \mathrm{~h}$. The absorbance of the samples was read at $570 \mathrm{~nm}$ and corrected for inference at $630 \mathrm{~nm}$.

24. In vitro microtubule polymerization: In vitro assay of microtubule polymerization was detected with the Tubulin Polymerization Assay (Cat.\# BK011P, Cytoskeleton Inc, Denver, CO, USA) Briefly, pure porcine brain tubulin proteins $(300 \mu \mathrm{g})$ in $100 \mu \mathrm{L}$ of GPEM buffer (80 mM PIPES, pH 6.9, $2 \mathrm{mM} \mathrm{MgCl}_{2}, 0.5 \mathrm{mM}$ EGTA, $1 \mathrm{mM} \mathrm{GTP}, 5 \%$ glycerol) were incubated with test compounds at $37{ }^{\circ} \mathrm{C}$. The alternation of tubulin polymerization was measured at absorbance 340 nm every $30 \mathrm{sec}$ for $30 \mathrm{~min}$ (Synergy 2; BioTek, Winooski, VT, USA). 
25. In vivo tubulin assembly assay: Cells were lysed in hypotonic buffer ( $1 \mathrm{mM} \mathrm{MgCl} 2,2 \mathrm{mM}$ EGTA, 0.5\% NP-40, $2 \mathrm{mM}$ PMSF, $200 \mathrm{Units} / \mathrm{ml}$ aprotinin, $5 \mathrm{mM}$ amino caproic acid, $1 \mathrm{mM}$ benzamidine, and $20 \mathrm{mM}$ Tris- $\mathrm{HCl}, \mathrm{pH} 6.8$ ) for $5 \mathrm{~min}$ at $37^{\circ} \mathrm{C}$ followed by centrifugation, $15,000 \times g$ for 10 min at $25^{\circ} \mathrm{C}$. The supernatant contained cytosolic tubulin. The pellets of polymerized tubulin were resuspended in hypotonic buffer and sonication. Both fractions were subjected to Western blot analysis for detection of tubulin contents. 
A

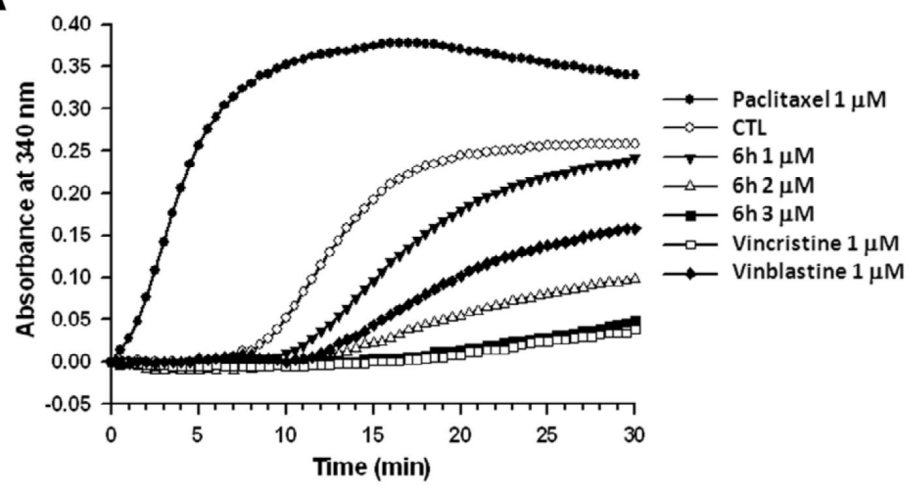

B

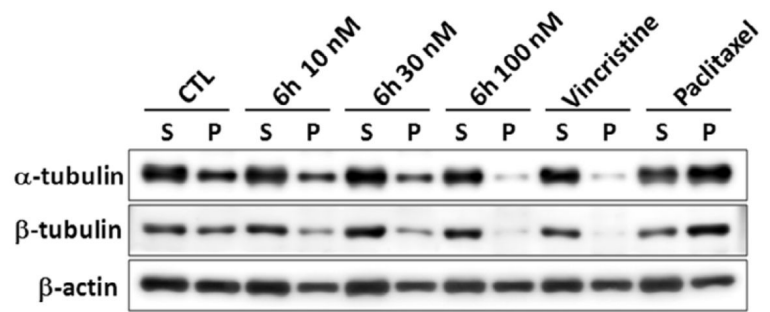

Figure 1.

Action mechanism of $\mathbf{6 h}$ for anti-proliferation of NCI-H522 non-small cell lung cancer cells. (A) Compound $\mathbf{6 h}$, vincristine, vinblastine, and paclitaxel were incubated with pure tubulin proteins in GPEM buffer. Alternation of tubulin assembly was recorded at absorbance 340 nm. (B) Cells were treated with vehicle (DMSO, as control), $6 \mathbf{h}$ (10 nM, $30 \mathrm{nM}$, and 100 $\mathrm{nM}), 100 \mathrm{nM}$ vincristine, and $100 \mathrm{nM}$ paclitaxel for $24 \mathrm{~h}$. Cytosolic (S, soluble) and cytoskeletal (P, polymerized tubulin) fractions were separated and followed by Western blot analysis for detection of $\alpha$-tubulin, $\beta$-tubulin, and $\beta$-actin protein expression. 

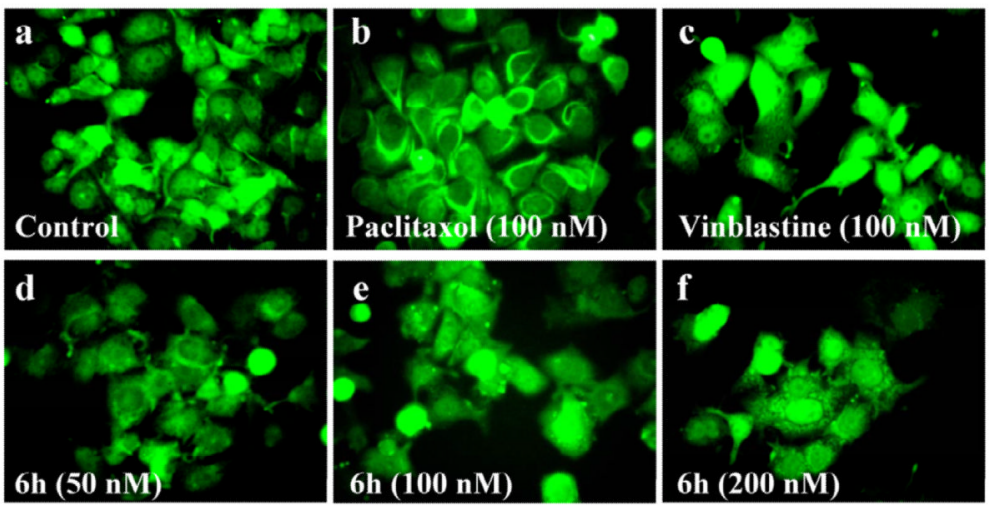

Figure 2.

Immunostaining of non-small cell lung cancer NCI-H522 with a-tubulin-FITC. (a) Control; (b) $24 \mathrm{~h}$ treatment with paclitaxel at $100 \mathrm{nM}$; (c) $24 \mathrm{~h}$ treatment with vinblastine at $100 \mathrm{nM}$; (d-f) $24 \mathrm{~h}$ treatment with $\mathbf{6 h}$ at $50 \mathrm{nM}, 100 \mathrm{nM}, 200 \mathrm{nM}$. 
<smiles>[R]c1cc2[nH]c(-c3cccc(OC)c3)cc(=O)c2cc1[R]</smiles>

2PQ-1: $\mathrm{R}^{6}, \mathrm{R}^{7}=-\mathrm{OCH}_{2} \mathrm{O}-$

2PQ-2: $R^{6}=$ pyrrolidinyl, $R^{7}=H$

2PQ-3: $R^{6}=$ morpholino, $R^{7}=H$

2PQ-4: $R^{6}=$ dimethylamino, $R^{7}=H$

Chart 1.

Structures of compounds 2PQ-1 4 
<smiles>[R]c1ccc(-c2cc(=O)c3c([R8])c([R])ccc3[nH]2)c([R])c1[R]</smiles>

$$
\begin{aligned}
& \text { 2PQ-5: } R^{5}=\mathrm{OH}, \mathrm{R}^{6}=\mathrm{OCH}_{3}, \mathrm{R}^{2}=\mathrm{F}, \mathrm{R}^{3^{\prime}}=\mathrm{R}^{4^{\prime}}=\mathrm{H} \\
& \text { 2PQ-6: } R^{5}=\mathrm{OH}, \mathrm{R}^{6}=\mathrm{OCH}_{3}, \mathrm{R}^{3}=\mathrm{F}, \mathrm{R}^{2}=\mathrm{R}^{4}=\mathrm{H} \\
& \text { 2PQ-7: } R^{5}=\mathrm{OH}, \mathrm{R}^{6}=\mathrm{OCH}_{3}, \mathrm{R}^{4^{\prime}}=\mathrm{F}, \mathrm{R}^{2}=\mathrm{R}^{3^{\prime}}=\mathrm{H} \\
& \text { 2PQ-8: } R^{5}=R^{6}=O H, R^{2}=F, R^{3}=R^{4}=H \\
& \text { 2PQ-9: } R^{5}=R^{6}=O H, R^{3^{\prime}}=F, R^{2^{\prime}}=R^{4^{\prime}}=H \\
& \text { 2PQ-10: } R^{5}=R^{6}=O H, R^{4}=F, R^{2}=R^{3}=H \\
& \text { 2PQ-6P: } R^{5}=\mathrm{OPO}_{3} \mathrm{Na}_{2}, \mathrm{R}^{6}=\mathrm{OCH}_{3}, \mathrm{R}^{3^{\prime}}=\mathrm{F}, \mathrm{R}^{2^{\prime}}=\mathrm{R}^{4^{\prime}}=\mathrm{H}
\end{aligned}
$$

Chart 2.

Structures of compounds2PQ-5 10 and 2PQ-5P 


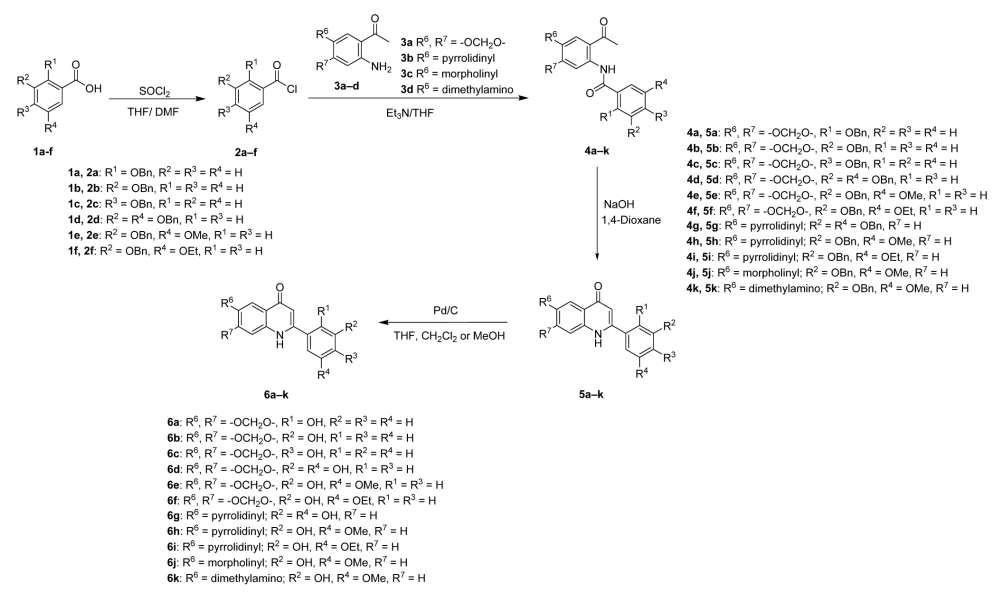

Scheme 1.

Synthesis of compounds $\mathbf{6 a}-\mathbf{k}$. 


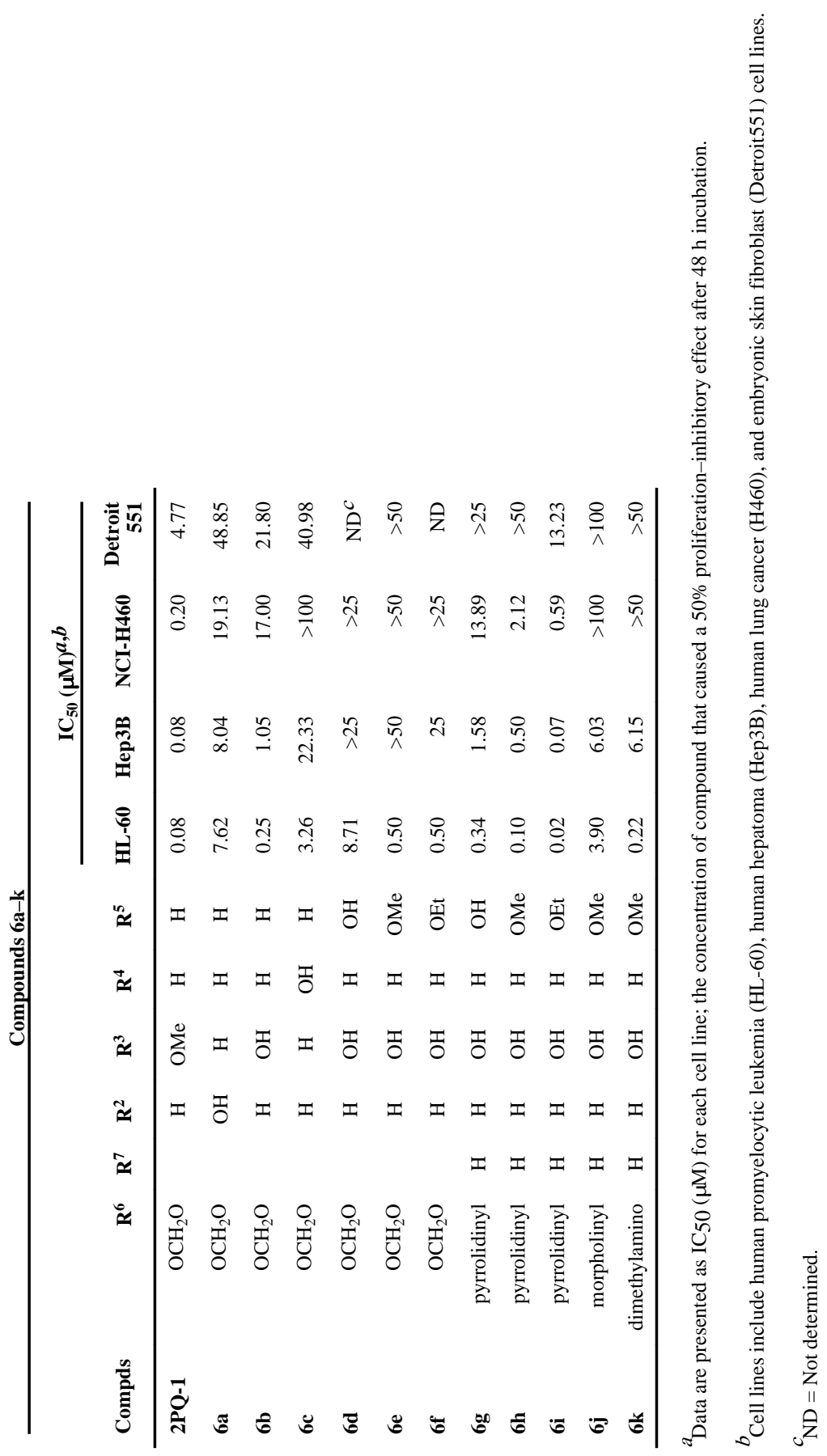


Table 2

Inhibition of in vitro tumor cell growth by compound $\mathbf{6 h} \mathbf{h}^{a}$

\begin{tabular}{lccc}
\hline Cell line $^{e}$ & $\operatorname{logGI}_{\mathbf{5 0}} \boldsymbol{b}$ & $\operatorname{logTGI}^{\boldsymbol{c}}$ & $\operatorname{logLC}_{\mathbf{5 0}} \boldsymbol{d}$ \\
\hline SR & $<-8.00$ & $>-4.00$ & $>-4.00$ \\
NCI-H522 & $<-8.00$ & $<-8.00$ & -5.41 \\
Colo205 & -7.27 & -6.66 & $-f$ \\
SF-295 & -6.96 & -4.95 & $>-4.00$ \\
M14 & -7.52 & -4.80 & $>-4.00$ \\
MDA-MB-435 & -8.00 & -7.53 & $-f$ \\
SK-MEL-5 & -7.61 & -7.18 & -6.31 \\
OVCAR-3 & -7.63 & -7.05 & -5.19 \\
NCI/ADR-RES & -7.21 & -6.29 & $>-4.00$ \\
SK-OV-3 & -7.63 & -4.60 & $>-4.00$ \\
RXF 393 & -7.39 & -4.62 & $>-4.00$ \\
DU-145 & -7.51 & -6.59 & $>-4.00$ \\
MDA-MB-468 & -6.58 & -5.70 & $>-4.00$ \\
\hline
\end{tabular}

a Data obtained from NCI's in vitro disease-oriented human tumor cells screen.

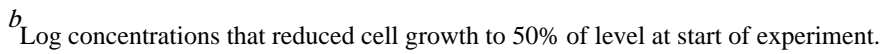

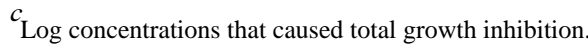

${ }^{d}$ Log concentrations that a given compound required to kill $50 \%$ of a test population.

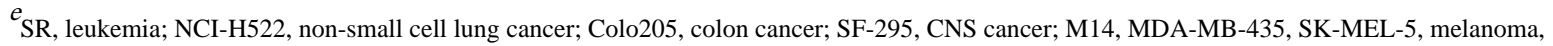
M14; OVCAR-3, NCI/ADR-RES, SK-OV-3, ovarian cancer; RXF 393, renal cancer; DU-145, prostate cancer; MDA-MB-468, breast cancer cell lines.

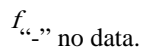


Table 3

Results of COMPARE correlations at $\mathrm{GI}_{50}$ level for compound $\mathbf{6 h}$

\begin{tabular}{clc}
\hline Rank & Compound (NCI number) & $\boldsymbol{r}^{\boldsymbol{a}}$ \\
\hline 1 & Vincristine sulfate (NSC 67574) & 0.538 \\
2 & Maytansine (NSC 153858) & 0.497 \\
3 & Vinblastine sulfate (NSC 49842) & 0.489 \\
4 & Rhizoxin (NSC 332598) & 0.476 \\
5 & DON (NSC 7365) & 0.452 \\
6 & Didemnin B (NSC 325319) & 0.450 \\
7 & AT-125 (NSC 163501) & 0.442 \\
8 & S-Trityl-L-cysteine (NSC 83265) & 0.421 \\
9 & Tiazofurin (NSC 286193) & 0.402 \\
10 & Trimetrexate (NSC 352122) & 0.401 \\
\hline
\end{tabular}

$a_{r=\text { correlation coefficient }}$ 